\title{
The metabolic effects of di (2-ethyl hexyl) phthalate medium dose on lipid profiles in serum and liver tissue
}

\author{
Buang $Y^{1,2}$ \\ 1 Department of Chemistry, Faculty of Science and Engineering, Nusa Cendana University, Kupang, Indonesia \\ 2 Laboratory of Applied Biochemistry, Department of Applied Biological Science, Saga University, Saga Shi, Honjo Machi-1, \\ Saga, Japan
}

\begin{abstract}
Abstrak
Latar belakang: Di (2-ethyl hexyl) phthalate merupakan bahan plasticizer yang banyak digunakan pada kantong darah untuk transfusi. Bahan ini dapat mempengaruhi metabolisme lipid. Penelitian ini bertujuan menyelidiki efek metabolik di (2-ethyl hexyl) phthalate dosis tengah pada profil lipid dalam serum dan jaringan hati.

Metode: Tikus percobaan galur Sprague Dawley diberi diet yang disuplementasi dengan 1,0\% di (2-ethyl hexyl) phthalate (kelompok DEHP, $n=5$ ) dan diet yang tak disuplementasi (kelompok kontrol, $n=5$ ) selama 10 hari. Hewan percobaan dibiarkan mendapatkan makanan secara ad libitum. Kadar lipid dalam serum diukur menggunakan enzyme assay kits. Lipid jaringan hati diekstraksi dan konsentrasinya ditentukan. Sepotong jaringan hati diambil untuk menentukan aktivitas malic enzyme dan carnitine palmitoyl transferase-1 (CPT-1).

Hasil: Kadar lipid serum kelompok DEHP menurun dibandingkan dengan kelompok kontrol $(P<0,05)$, di mana kadar lipid serum (mg/dL) pada kelompok kontrol dan DEHP masing-masing: trigliserida (TG) $(100,5 \pm 16,5)$ dan $(31,2 \pm 1,7)$; fosfolipid (PL) $(143,3 \pm 7,8)$ dan $(88,9 \pm 3,2) ;$ kolesterol total $(88,7 \pm 4,6)$ dan $(51,9 \pm 2,3)$; dan kolesterol HDL (high-density lipoprotein) $(29,8 \pm 1,0)$ dan $(16,1 \pm 0,7)$. Kandungan PL hati pada kelompok DEHP meningkat secra bermakna dibandingkan dengan kelompok kontrol $(P<0,05)$; peningkatannya mencapai $15 \%$. Kandungan lipid hati $(\mathrm{mg} / \mathrm{g}$ jaringan) pada kedua kelompok masing-masing: TG $(40,8 \pm 4,4)$ dan $(23,7 \pm 1,3)$; kolesterol total $(3,36 \pm 0,29)$ dan $(2,33 \pm 0,23) ; P L(36,5 \pm 1,0)$ dan $(41,7 \pm 0,6)$. Aktivitas malic enzyme dan CPT-1 masing-masing meningkat sebesar 4,35 dan 2,33 kali kelompok kontrol.

Kesimpulan: Di (2-ethyl hexyl) phthalate dosis tengah menurunkan sekresi lipid dari sel-sel hati ke dalam aliran darah. Kandungan TG dan kolesterol total sel-sel hati juga berkurang, sebaliknya kadar fosfolipid hati meningkat. Peningkatan fosfolipid hati disertai peningkatan aktivitas malic enzyme dan CPT-1 merupakan faktor utama penurun kadar lipid serum, TG dan kolesterol sel-sel hati yang diinduksi oleh di (2-ethyl hexyl) phthalate. (Med J Indones 2011; 20:20-6)
\end{abstract}

\begin{abstract}
Background: Di (2-ethyl hexyl) phthalate is the most widely used plasticizer in blood storage bag for transfusion. This substance can modify lipid metabolism. This study was aimed to elucidate the metabolic effects of di (2-ethyl hexyl) phthalate medium dose on lipid profiles in serum and liver tissue.

Methods: Sprague Dawley rats were fed 1.0\% di (2-ethyl hexyl) phthalate diet (DEHP group, n=5) or a non-supplemented diet (control group, $n=5$ ) for 10 days. The rats were allowed to freely access each food. Serum lipid concentrations were measured using enzyme assay kits. Lipids of liver tissues were extracted and the lipid contents were determined. A peach of liver was prepared to determine the activities of malic enzyme and carnitine palmitoyl transferase-1 (CPT-1).

Results: Serum lipid concentrations $(\mathrm{mg} / \mathrm{dL})$ of DEHP group decreased compared to control $(\mathrm{P}<0.05)$. The serum triglyceride (TG) concentrations of control and DEHP groups were respectively $(100.5 \pm 16.5)$ and $(31.2 \pm 1.7)$; phospholipid (PL), (143.3 \pm 7.8$)$ and (88.9 \pm 3.2$)$; total cholesterol, (88.7 \pm 4.6$)$ and (51.9 \pm 2.3$)$. The liver TG content of control and DEHP group (mg/g liver) were respectively, (40.8 \pm 4.4$)$ and $(23.7 \pm 1.3)$; liver cholesterol were (3.36 \pm 0.29$)$ and (2.33 \pm 0.23$)$; and the liver PL were $(36.5 \pm 1.0)$ and (41.7 \pm 0.6$)$. Malic enzyme and CPT-1 activities (nmol/min/ $\mathrm{mg}$ protein) of DEHP group increased compared to control $(\mathrm{P}<0.05)$, in which their increases were approximately by 4.35- and 2.33-folds, respectively.

Conclusion: The di (2-ethyl hexyl) phthalate medium dose attenuates lipids secretion from the liver cells into the bloodstream. The increase of liver PL level accompanied with the promotions of malic enzyme and the CPT-1 activities are the key factors of the dietary di (2-ethyl hexyl) phthalate effects in rats to attenuate the lipid secretions from the livers. (Med J Indones 2011; 20:20-6)
\end{abstract}

Key words: Di (2-ethyl hexyl) phthalate, hyperphospholipids, lipolysis, liver lipids, serum lipids

Di (2-ethyl hexyl) phthalate is the most widely used plasticizer in polyvinyl chloride plastic. It was reported that di(2-ethyl hexyl) phthalate used inblood storagebags leaches out in significant amounts into the blood stored and the blood products resulted from exposure of patients to this compound during transfusion..$^{1-3}$ It was also reported Correspondence email to: pajohn_buang@hotmail.com that after 21 days storage of blood used to transfuse in human recipients, the blood storage bags averagely leaches out $10 \mathrm{mg}$ di (2-ethyl hexyl) phthalate $100 \mathrm{~mL}$ blood. Furthermore, a number of reports are available on the toxicity of di (2-ethyl hexyl) phthalate, particularly studied in the liver., ${ }^{4,5}$ Almost all of those studies carried 
out the treated doses reached $200 \mathrm{mg} / 100 \mathrm{~g}$ body weight (BW). Gayathri et al. ${ }^{6}$ administered the rats with a dose of $0.75 \mathrm{mg} / 100 \mathrm{~g}$ BW which is equivalence with transfusion of ten unit of blood in a human recipient. These authors did not find the serious toxic effects as evidenced by lack of any histopathological changes in the liver or significant alterations in many biochemical parameters. Overall, the doses of di (2-ethyl hexyl) phthalate that had been treated have ranges $750 \mu \mathrm{g}-200 \mathrm{mg}$ per $100 \mathrm{~g}$ BW. Therefore, the dose of $75 \mathrm{mg}$ di (2-ethyl hexyl) phthalate $/ 100 \mathrm{~g} \mathrm{BW}$ that was used in the present study might be considered medium dose.

Currently, di (2-ethyl hexyl) phthalate, a phthalate plasticizer, belongs to a peroxisome proliferators class of rodent nongenotoxic hepatocarcinogens. ${ }^{7,8}$ This phthalate modulates the peroxisome proliferatorsactivated receptor (PPAR). ${ }^{9}$ PPAR $\alpha$ is known as lipidactivated transcription factors expressed in the liver that belongs to the nuclear hormone superfamily. Numerous authors ${ }^{7-9}$ reported that di (2-ethyl hexyl) phthalate is the essential transcription factors regulating key cellular functions that include lipid metabolism.

Some biochemical parameters in lipid metabolism such as serum lipid profiles are constantly altered during normal states or disorders of metabolisms. Very-low density lipoprotein is a lipoprotein handling the lipid transportation from the synthesized lipid in the liver into extra hepatic tissues. Hence, serum lipid profiles generally indicate how lipid metabolism occurred in the liver. Commonly, disorders of lipid metabolism in the liver such as fat infiltration induce hepatic steatosis. ${ }^{10-12}$ The impacts of the hepatic steatosis is similar to those seen in patients with alcoholic liver disease and range from mild hepatic steatosis to steatohepatitis, liver fibrosis, and cirrhosis, ${ }^{13}$ and, rarely, to hepatocellular carcinoma. ${ }^{14}$

Considering di (2-ethyl hexyl) phthalate is widely used in consumer products in common society such as food packaging materials and children's toys ${ }^{15}$ and used for tubing and containers for blood transfusions and blood products, etc., di (2-ethyl hexyl) phthalate constantly and directly or indirectly interacts with human and animal health cells. Therefore, its effect on lipid profiles in serum and liver tissue is of interested to evaluate. The present study was conducted to elucidate the metabolic effects of di (2-ethyl hexyl) phthalate medium dose on lipid profiles in serum and liver tissue using spraguedawley (SD) rats as animal model.

\section{METHODS}

\section{Animals and experimental design}

All aspects of the experiment were conducted according to guidelines provided by the ethical committee of experimental animal care at Saga University (Saga, Japan). Male SD-rats aged 5 weeks were housed individually in an air-conditional room $(24 \mathrm{oC})$ with a 12-h light/dark cycle. After one week acclimatization, rats were assigned to two groups (five rats each). Control diet (as control group) was prepared according to recommendations of the American Institute of Nutrition (AIN) and contained (in weight \%) 20 of casein, 10 of safflower oil, 1 of vitamin mixture (AIN-93), 3.5 of mineral mixture (AIN-93), 10 of sucrose, 0.25 of choline bitartrate, 0.3 of L-Cystein, 0.0014 of t-BHQ, 5 of cellulose, 13.2 of $\alpha$-cornstarch, and $\beta$-cornstarch to make 100. The di (2-ethyl hexyl) phthalate diet (as DEHP group) was prepared by replacement of $1.0 \%$ $\beta$-cornstarch with di (2-ethyl hexyl) phthalate to the control diet. Considering evidences in food intake and final BW of the dietary di (2-ethyl hexyl) phthalate in male SD-rats, the $1 \%$ of food intake is equally to a range of 73-77 $\mathrm{mg}$ di (2-ethyl hexyl) phthalate/100g BW dose. ${ }^{16}$ The animals received the diets for 10 days. At the end of the feeding period, rats were killed by decapitation after a 9-h starvation. Livers were excised immediately, and serum was separated from blood.

\section{Analyses of serum and liver lipids}

Liver lipids were extracted according to the method of Folch et al., ${ }^{17}$ and concentrations of TG, cholesterol, and phospholipids (PL) were measured by the methods used elsewhere. ${ }^{10-12,18,19}$ Serum TG, PL, cholesterol, and glucose were measured using enzyme assay kits from Wako Pure Chemicals according to the manufacture's instructions.

\section{Preparation of liver sub cellular fractions}

The mitochondrial and cytosol of liver sub cellular fractions were prepared as previously reported by Nagao et al. ${ }^{19}$ Protein content was determined by the method used in our previous studies..$^{10-12,18,19}$

\section{Assays of hepatic enzyme activity}

The malic enzyme (ME, EC1.1.1.40), the carnitine palmitoyl transferase-1 (CPT-1; EC2.3.1.23), glucose 6-phosphate dehydrogenase (G6PDH; EC1.1.1.49), fatty acid synthase (FAS; EC2.3.1.85), phosphatidate phosphohydrolase (PAP, EC3.1.3.4) activities were 
determined by the methods used in our previous studies. ${ }^{10-}$ ${ }^{12,18,19}$ The glutathione peroxidase (GSH-Px; EC1.11.1.9) was determined by the methods used elsewhere. ${ }^{20,21}$

\section{Statistical analyses}

All values are expressed as mean \pm standard error of the mean (SEM). Data were analyzed by one-way analysis of variance, and all differences were inspected by Duncan's new multiple-range test using SPSS statistical software (SPSS inc., Chicago, IL, USA).

\section{RESULTS}

\section{Dietary di (2-ethyl hexyl) phthalate promoted liver weight}

The daily food intake is shown in Table 1 . The food intake of DEHP group decreased in comparison to control. The low level of food intake in the group was equivalent with the reduction of body weight. However, the weights of liver were significantly higher than that of the control group $(\mathrm{P}<0.05)$.

\section{Effects of di (2-ethyl hexyl) phthalate on glucose blood level, serum and liver lipid levels}

As shown in Figure 1, the lipid levels in serum of DEHP group decreased significantly $(\mathrm{P}<0.05)$, in which serum TG, PL, total cholesterol, and HDL-cholesterol levels decreased approximately by $70 \%, 38 \%, 41 \%$, and $46 \%$, respectively. Although failed to reach significant level, the glucose blood level decreased by approximately $9 \%$.

Table 1. The metabolic effects of di(2-ethyl hexyl) phthalate on growth parameters

\begin{tabular}{lrr}
\hline Group & \multicolumn{1}{c}{ Control } & \multicolumn{1}{c}{ DEHP* } \\
\hline Initial body weight $(\mathrm{g})$ & $132.8 \pm 3.4$ & $134.6 \pm 2.5$ \\
Final body weight $(\mathrm{g})$ & $206.1 \pm 3.5^{\mathrm{a}}$ & $188.4 \pm 6.3^{\mathrm{b}}$ \\
Food intake $(\mathrm{g} /$ day $)$ & $18.7 \pm 0.8^{\mathrm{a}}$ & $14.1 \pm 0.8^{\mathrm{b}}$ \\
Liver weight $(\mathrm{g} / 100 \mathrm{~g}$ body weight $)$ & $4.0 \pm 0.1^{\mathrm{a}}$ & $6.7 \pm 0.2^{\mathrm{b}}$ \\
\hline
\end{tabular}

Values are expressed as mean \pm SEM of five rats. Clearly define $a \& b$ indicates significant difference at $\mathrm{P}<0.05$. ${ }^{*} \mathrm{DEHP}$, di(2-ethyl hexyl) phthalate
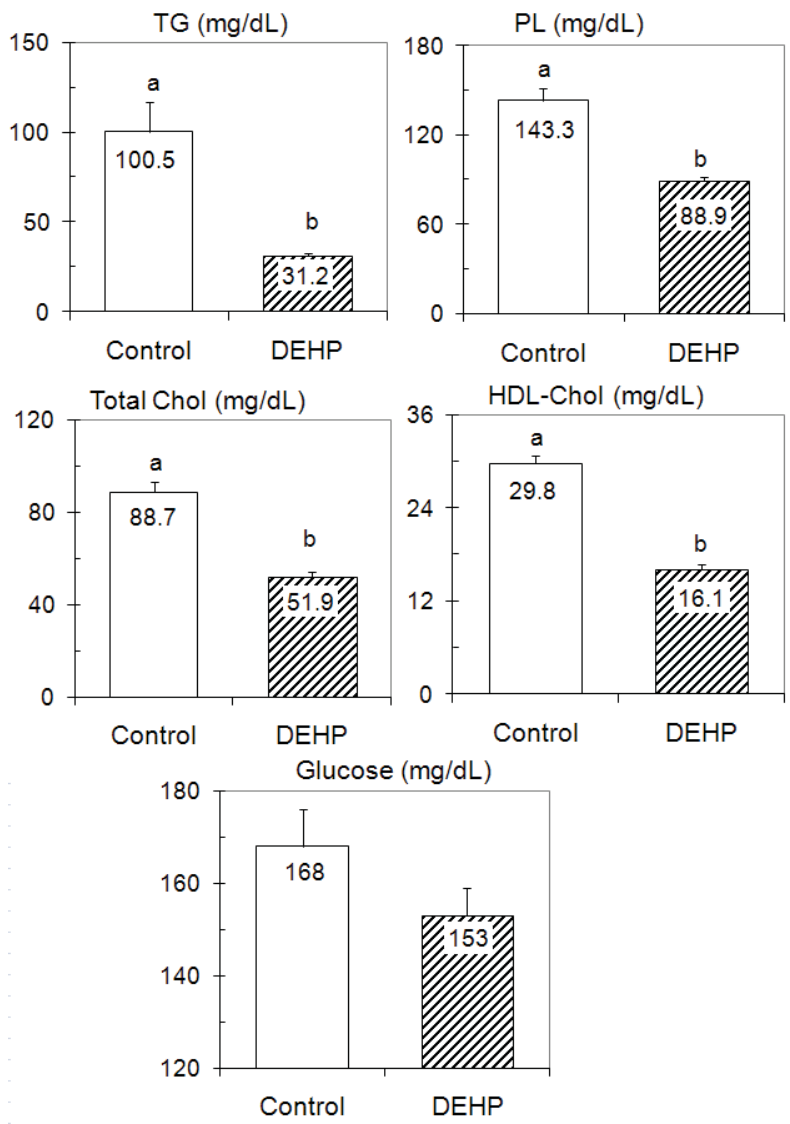

Figure 1. Serum lipids and glucose levels 
Figure 2 shows the differences in liver lipid contents. Dietary di (2-ethyl hexyl) phthalate promoted significantly the liver PL content than that of the control group $(\mathrm{P}<0.05)$. The level was promoted approximately by $15 \%$. Both liver
TG and liver cholesterol contents, however, decreased significantly in the group $(\mathrm{P}<0.05)$. The decreases were approximately by $73 \%$ and $44 \%$, respectively.
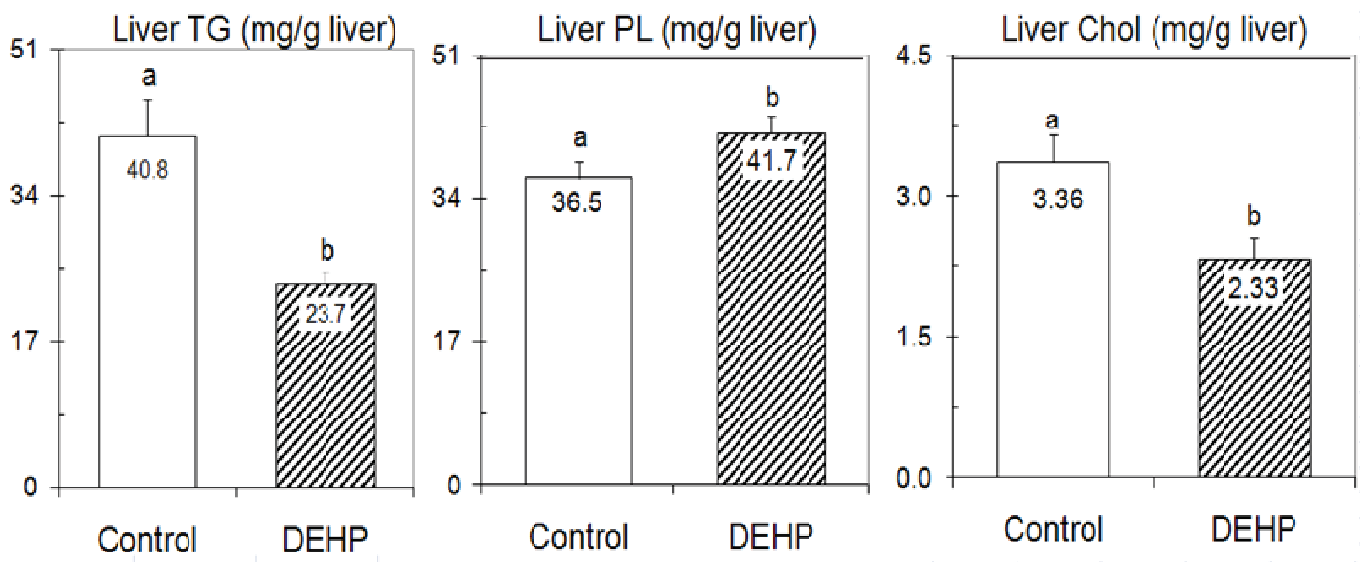

Figure 2. The liver lipids content

Values are expressed as mean \pm SEM of five rats. Clearly define a \& b indicates significant difference at $P<0.05$

Effects of di (2-ethyl hexyl) phthalate on the activities of malic enzyme and carnitine palmitoyl transferase-1

Figure 3 shows the activities of enzymes determined in present study. Compared to control, both malic enzyme and CPT-1 activities of DEHP group increased significantly $(\mathrm{P}<0.05)$, in which the increases were approximately by 4.35 - and 2.33-folds, respectively. The activities of G6PDH and PAP slightly increased that were approximately by $12 \%$ and $5 \%$, respectively. However, FAS activity decreased slightly. Furthermore, the activity of antioxidant enzyme represented by GSHPx decreased significantly $(\mathrm{P}<0.05)$.
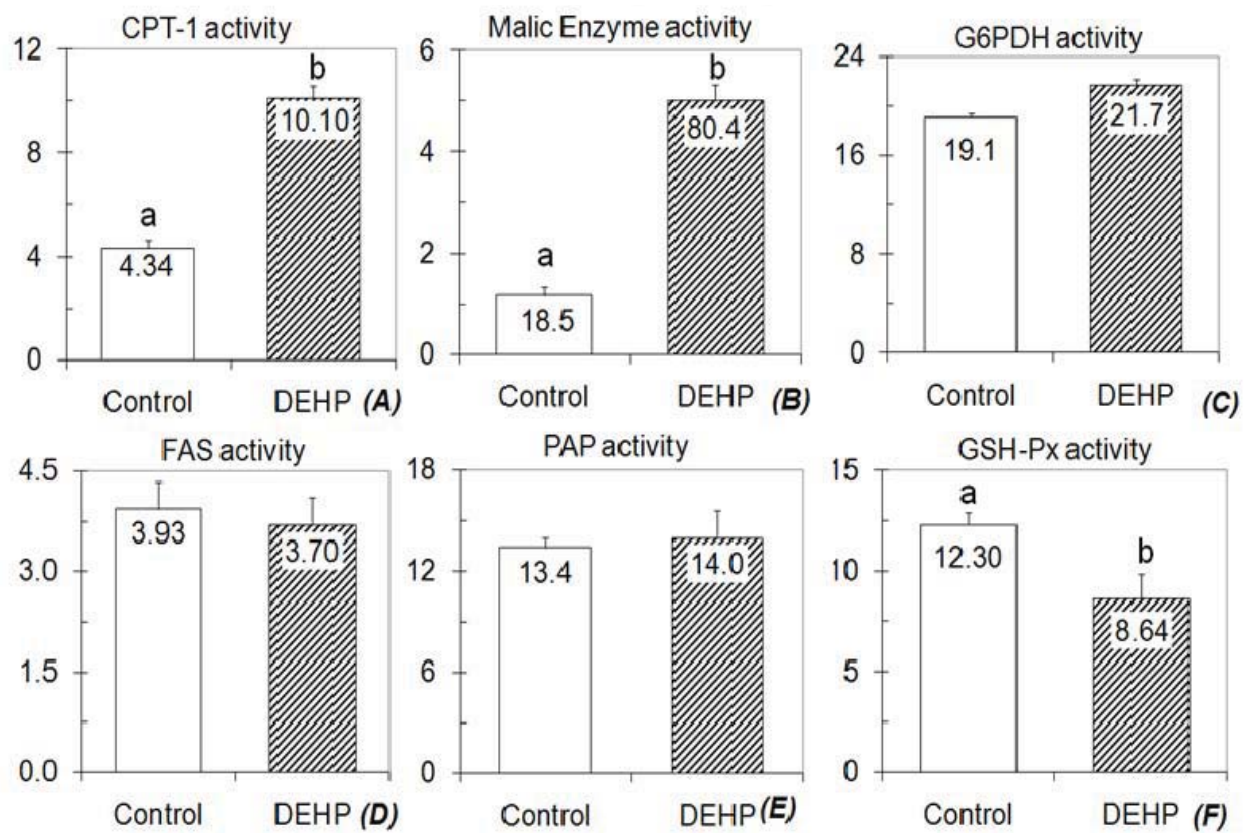

Figure 3. Metabolic responses regulated by di (2-ethyl hexyl) phthalate on liver enzyme activities (in $\mathrm{nmol} / \mathrm{min} / \mathrm{mg}$ protein)

Values are expressed as mean \pm SEM of five rats. Clearly define a \& b indicates significant difference at $P<0.05$ 


\section{DISCUSSION}

Di (2-ethyl hexyl) phthalate modulates the $\mathrm{PPAR}^{9}$ and is an essential transcription factors regulating lipid metabolism..$^{7-9,16}$ The present study found that orally intake of $1.0 \%$ di (2-ethyl hexyl) phthalate diet reduced markedly serum lipid level. The intake also attenuated liver TG and cholesterol contents, however promoted liver phospholipids level. The malic enzyme and CPT-1 activities increased markedly. The promotions of these enzyme activities and the liver phospholipids level are the key factors of the metabolic effects of di (2-ethyl hexyl) phthalate in attenuations of serum lipids and the liver TG and cholesterol contents.

The di (2-ethyl hexyl) phthalate dose applied in present treatment was $1.0 \%$ of food intake; and by considering those food intakes and the body weights of the animal treated (Table 1), the dose of the present treatment was of $75 \mathrm{mg}$ di (2-ethyl hexyl) phthalate per $100 \mathrm{~g} \mathrm{BW}$. This dose was in the range of currently treated which is $750 \mu \mathrm{g}-200 \mathrm{mg}$ per $100 \mathrm{~g} \mathrm{BW}{ }^{6}$ As shown in Table 1, the liver weight of DEHP group increased significantly compared to control $(\mathrm{P}<0.05)$. The decrease in final body weight however might be suitable with low food intakes of the rats in the group. Overall, the applied 75 mg di (2-ethyl hexyl) phthalate/100 g BW dose to the rats developed hepatomegaly.

Hepatomegaly is known as an abnormal enlargement of the liver. The enlargements of the liver size by this treatment (Table 1) indicate a disorder of metabolism including lipid metabolism in the liver tissue. Therefore, serum and liver lipids levels were important to determine. The decreases of serum lipid levels (Fig. 1) suggested that dietary di (2-ethyl hexyl) phthalate attenuated lipids secretion from the liver tissue into the bloodstream. The decrease of lipid levels secreted from the liver therefore might cause their content in the liver decreased. The decrease of liver TG and cholesterol content accompanied with a promotion of liver PL level (as shown in Fig. 2) is consistent with the reports of Yanagita et al. ${ }^{16}$ that intake of $1 \%$ di (2-ethyl hexyl) phthalate in rats induces hyperphospholipids of the liver tissue but attenuates TG and cholesterol levels. Therefore, di (2-ethyl hexyl) phthalate intake in the present study attenuated the serum lipid level and also the liver TG and cholesterol levels, but promoted liver PL content.

The increased PL content of liver tissue might indicate a promotion of PPAR $\alpha$, the PPAR expressed in the liver. Burns and Heuve ${ }^{22}$ reported that phosphorylation modulates PPAR $\alpha$ and affects these receptors activities to control a variety of target genes involved in lipid homeostasis. Latruffe et al. ${ }^{23}$ and Howarth et al. ${ }^{24}$ found that di (2-ethyl hexyl) phthalate administered to rats lead to increase the volume and density of peroxisomes in the liver cells. Both those later authors also reported that during peroxisome proliferations, di (2-ethyl hexyl) phthalate stimulate the transcription of genes encoding enzymes of lipid metabolism, particularly fatty acid betaoxidation in a PPAR-dependent manner. Our previous study found that the increased fatty acid degradation is associated with the promotion of liver PL level. ${ }^{11}$ The promotions of liver PL level might indicate that those receptors are activated and therefore fatty acid degradation increased. The increased fatty acid degradation (Figure 3A) accompanied with unchanged activities of FAS and PAP between the groups might indicate a decrease of fatty acyl-CoA level, a substrate provided for TG biosynthesis; therefore liver TG content decreased (Figure 2). Furthermore, the increased fatty acid degradation in the liver tissue might indicate an enhancement of Krebs cycle to deliver adenosine triphosphate. The enhancement of Krebs cycle rate can be elucidated from some parameters of anaplerotic reactions.

Anaplerotic reaction is a filling up mechanism of Krebs cycle catalyzed by several enzymes. One biocatalyst involved in this mechanism is malic enzyme. Malic enzyme converses pyruvate to malate, a member of Krebs cycles. The increased malate concentration promotes the rate of Krebs cycle. The markedly increased malic enzyme activities found in DEHP group (as shown in Figure 3B) suggested that di (2-ethyl hexyl) phthalate intake in present dose could promote pyruvate conversion into malate. The increased conversion of pyruvate into malate accompanied with the increased G6PDH activity (Figure 3C) might induce rates of glycolysis to metabolize glucose and therefore deliver pyruvate. The pyruvate further plays as a starting molecule in biosynthesis of malate and ribose, a key molecule in nucleic acid nucleotide formations. This mechanism was reasonable because serum glucose level decreased (Figure 1) although it failed to reach significant level $(\mathrm{P}<0.05)$. Hence, the decreased serum glucose level might indicate a promotion of glucose uptake by the liver cell as results of gradient concentration occurred between bloodstream and liver cytosolic cellular fractions. Furthermore, the decreased activities of antioxidant enzyme represented by GSHPx might indicate that toxicity of medium dose of di (2-ethyl hexyl) phthalate used in present treatment might still appear in liver. Overall, considering all alterations of those enzyme activities, the flow chart 
describing anaplerotic reaction induced by di (2-ethyl hexyl) phthalate was depicted in Figure 4.

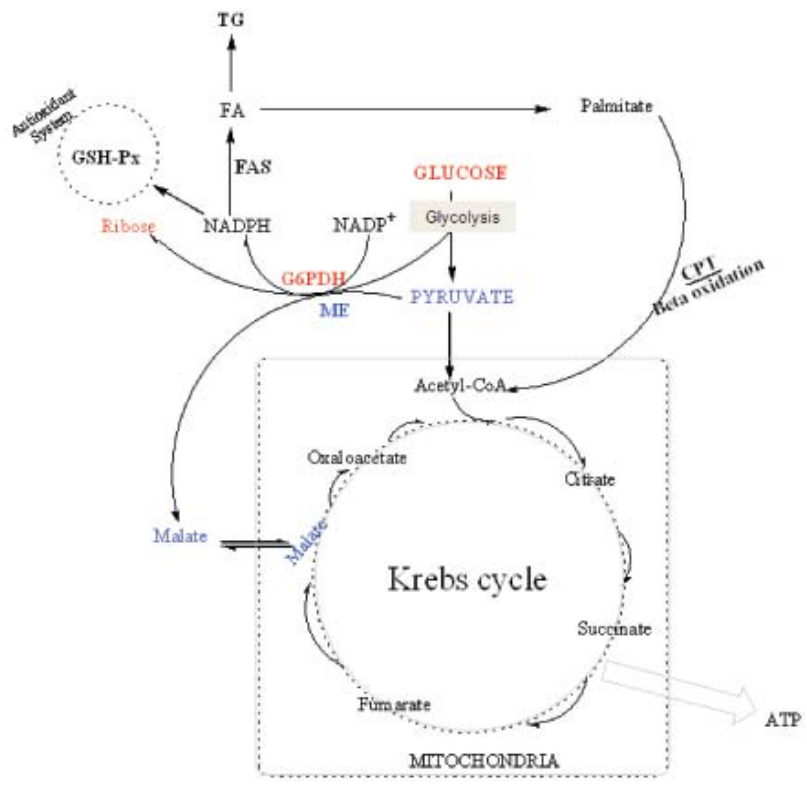

Figure 4. The pathways of anaplerotic reactions and the fatty acid degradation

Red, pentose phosphate pathway; blue, Pyruvate converted into malate catalyzed by malic enzyme

GSH-Px, glutathione peroxidase; NADP, nicotinamide adenine dinucleotide phosphate; G6PDH, glucose 6-phosphate dehydrogenase; ME, malic enzyme; FA, fatty acid; FAS, fatty acid synthase; TG, triglyceride; CPT, carnitine palmitoyl transferase; ATP, adenosine triphosphate

In conclusion, the ingestion of di (2-ethyl hexyl) phthalate in rats decreased levels of serum and liver lipids, except liver phospholipids. The promotion of liver phospholipids content induced activities of malic enzyme and CPT-1. Both these enzymes play essential roles in metabolic responses regulated by the di (2-ethyl hexyl) phthalate in lipid metabolism. The application of di (2-ethyl hexyl) phthalate in accurately dose might be one of the beneficial strategies in development of hypolipidemic drugs to secure the vessel blood from the attached lipids.

\section{Acknowledgments}

The author would like to express high appreciation for the suggestions and the continued encouragement from Prof. Teruyoshi Yanagita, the Professor of Saga University, and the excellent assistance and useful commands from Dr. Koji Nagao in enzymatic determinations and the excellent assistance from Dr. Yu-Ming Wang in handling instruments and animals. The author also would like to give thanks to the Japanese Monbukagakusho for providing the fund of the research.

\section{REFERENCES}

1. Hildenbrand SL, Lehmann HD, Wodarz R, Ziemer G, Wendel HP. PVC-plasticizer DEHP in medical products: do thin coatings really reduce DEHP leaching into blood? Perfusion J. 2005; 20: 351-7.

2. Koch HM, Bolt HM, Preuss R, Eckstein R, Weisbach V, Angerer J. Intravenous exposure to di(2-ethylhexyl) phthalate (DEHP): metabolites of DEHP in urine after a voluntary platelet donation. Arch Toxicol. 2005; 79: 689-93.

3. Takahashi Y, Shibata T, Sasaki Y, Fujii H, Bito Y, Suehiro S. Di(2-ethylhexyl) Phthalate Exposure During Cardiopulmonary Bypass. Asian Cardiovasc Thorac Ann 2008; 16: 4-6.

4. Hinberg I. DEHP in Medical Devices: An Exposure and Toxicity Assessment. Research \& Surveillance Division, Medical Devices Bureau Therapeutic Products Directorate, Health Canada. 2002.

5. Ghosh J, Das J, Manna P, Sil PC. Hepatotoxicity of di-(2ethylhexyl) phthalate is attributed to calcium aggravation, ROS-mediated mitochondrial depolarization, and ERK/ NF- $\kappa \mathrm{B}$ pathway activation. Free Radic Biol Med. 2010; 49(11):1779-91.

6. Gayathri NS, Dhanya CR, Indu AR, Kurup PA. Changes in some hormones by low doses of di(2-ethylhexyl) phthalate (DEHP), a commonly used plasticizer in PVC blood storage bags and medical tubing. Indian J Med Res. 2004; 119: 139-44.

7. MelnickRL. Is peroxisome proliferation an obligatory precursor step in the carcinogenicity of di(2-ethylhexyl)phthalate (DEHP)?. Environ Health Perspect. 2001; 109(5):437-42.

8. Hasmall SC, James NC, Macdonald N, Soames AR, Roberts RA. Species differencies in response to diethylhexyl phthalate: Supression of apoptosis, induction of DNA synthesis and peroxisome proliferator activated receptor alfa-mediated gene expression. Arch Toxicol. 2000; 74: 85-91.

9. Roberts RA, James NH, Hasmall SC, Holden PR, Lambe $\mathrm{K}$, Macdonald $\mathrm{N}$, et al. Apoptosis and proliferation in nongenotoxic carcinogenesis: species differences and role of PPR $\alpha$. Toxicol. [letter] 2000, 112: 49-57.

10. Buang Y, Cha JY, Nagao K, Wang YM, Inoue N, Yanagita T. Alleviation of fatty liver by $\alpha$-linolenic acid. J Nutr Sci Vitaminol. 2004; 50: 272-6.

11. Buang Y, Wang YM, Cha JY, Nagao K, Yanagita T. Dietary phosphatidylcholine alleviates fatty liver induced by orotic acid. Nutrition 2005; 21: 867-73.

12. Buang Y, Ola PD, Yanagita T. Dietary shochu kasu alleviates fatty liver induced by orotic acid. Bangladesh J Pharmacol 2010; 5: 57-61.

13. Dixon JB, Bhathal PS, O'Brien PE. Nonalcoholic fatty liver disease: Predictors of nonalcoholic steatohepatitis and liver fibrosis in the severely obese. Gastroenterology 2001;121:91-100.

14. Cotrim HP, Parana R, Braga E. Nonalcoholic steatohepatitis and hepatocellular carcinoma: natural history. Am J Gastroenterol. 2000; 95:3018-9.

15. Michalik L, Auwerx J, Berger JP, Chatterjee VK, Glass CK, Gonzalez FJ, et al. International Union of Pharmacology. LXI. Peroxisome proliferator-activated receptors. Pharmacol. Rev., 2006; 58(4): 726-41. 
16. Yanagita T, Satoh M, Enomoto N, Sugano M. Di (2-ethyl hexyl) phthalate enhances hepatic phospholipids synthesis in rats. Bioch. Biophys. Acta 1987; 919: 64-70.

17. Folch J, Lees M, Sloane-Starley GH. A simple method for the isolation and purification of total lipids from animal tissues. J. Biol. Chem.1957; 226:497-509.

18. Cha JY, Cho YS, Kim I, Anno T, Rahman SM, Yanagita T. Effect of hesperetin, a citrus flavonoid, on the liver triacylglycerol content and phosphatidate phosphohydrolase activity in orotic acid-fed rats. Plant Foods for Human Nutrition, 2001; 56(4):349-58.

19. Nagao K, Wang YM, Inoue N, Han SY, Buang Y, Noda T, et al. The 10trans, 12cis isomer of cunjugated linoleic acid promotes energy metabolism in OLETF rats. Nutrition. 2003; 19(7-8): 652-6.

20. Hawkes WC. Association of glutathione peroxidase activity with insulin resistance and dietary fat intake during normal pregnancy. The Journal of Clinical Endocrinology \& Metabolism. 2004; 89(9): 4772-3.

21. Blankenberg S, Hans J. Rupprecht HJ, Bickel C, Torzewski M, Hafner G, Tiret T, et al. Glutathione peroxidase 1 activity and cardiovascular events in patients with coronary artery disease. N Engl J Med. 2003; 349:1605-13.

22. Burns KA, Heuvel JPV. Review: Modulation of PPAR activity via phosphorylation. Biochimica et Biophysica Acta (BBA) Molecular and Cell Biology of Lipids 2007; 1771: 952-60.

23. Latruffe NM, Malki C, Nicholas-Frances V, Jannin B, Clemencet MC, Hansmannel F, et al. Peroxisome proliferatoractivated receptors as physiological sensors of fatty acid metabolism: molecular regulation in peroxisomes. Biochem Soc Transac. 2000; 29: 305-9.

24. Howarth JA, Price SC, Dobrota M, Kentish PA, Hinton RA. Effects on male rats of di (2-ethyl hexyl) phthalate and di-n hexylphthalate administered a lone or in combination. Toxicol [letters] 2001: 35-43. 